\title{
Unconventional Myosin-Va
}

National Cancer Institute

\section{Source}

National Cancer Institute. Unconventional Myosin-Va. NCI Thesaurus. Code C122883.

Unconventional myosin-Va (1855 aa, $215 \mathrm{kDa}$ ) is encoded by the human MYO5A gene.

This protein is involved in the transport of cytoplasmic cargo along actin filaments. 